\title{
Effect of feeding Tephrosia bracteolate on the bioavailability of macro minerals in goat
}

\section{AM Ogungbesan ${ }^{1 *}$, GA Adeleke ${ }^{1}$, OE Fasina $^{1}$ and AN Fajemisin ${ }^{2}$}

${ }^{1}$ Department of Animal Production, College of Agricultural Science, Yewa Campus Ayetoro Olabisi Onabanjo University Ago-Iwoye, Ogun State, Nigeria; ${ }^{2}$ Department of Animal Production and Health, Federal University of Technology Akure, Nigeria

\begin{abstract}
Sixteen West African Dwarf Goats ( 8 bucks and 8 does) were balanced for age, sex and weight (average of $5.79 \pm 0.60 \mathrm{~kg}$ ), to evaluate the effect of Tephrosia bracteolata (Tb) on macro mineral utilization. To examine the effect of Tephrosia bracteolata (Tb), different levels of Tb were used (Tb20, Tb40, Tb60 and Tb80). Ca absorbed ( $\mathrm{gm}$ ) ranged from 0.64 (Tb20) to 1.57 (Tb80) and Ca retention was from 0.62 ( Tb20) to 1.56 ( Tb80) which was partially linear. In both absorption and retention of $\mathrm{Ca}, \mathrm{Tb} 20$ and Tb80 found the lowest $(P<0.05)$ and the highest $(P<0.05)$ value respectively. Like Ca, $P$ also followed the same trend in case of retention and absorption as well. Concerning $\mathrm{Mg}$, the lowest $(0.41,0.40)$ and the highest $(0.67,0.65)$ absorbed and retained value $(\mathrm{g} /$ day) was observed in Tb 20 and Tb 80 respectively. Tb80 showed significantly higher $\mathrm{Na}$ absorption than Tb20. In case of $\mathrm{Na}$ retention, Tb80 showed the highest $(\mathrm{P}<0.05)$ retention than other groups. In $\mathrm{K}$ absorption $(\mathrm{g} / \mathrm{day})$, increasing trends $(\mathrm{P}<0.05)$ were observed from Tb20 (0.44) to Tb80 (1.25). In case of retention, Tb80 found the highest $(P<0.05) \mathrm{K}$ retention than other groups. These positive balances of minerals result linearly appreciating with the increase of $T$. bracteolata in the diets which might be due to leguminous properties in $T$. bracteolata. $T$. bracteolata can be used as a roughage source for goats without any remarkable adverse or, side or ill effects which affect the well-being of animals feeding.
\end{abstract}

Keywords: leguminous, Tephrosia bracteolata, macro mineral, West African dwarf goat

Bangladesh Animal Husbandry Association. All rights reserved. Bang. J. Anim. Sci. 2020. 49 (2):119-127

\section{Introduction}

The importance of forage legume has been emphasized over the years and they form a very important part of goat diets especially in rural areas. The presence of mineral elements in animal feeds is vital for animal metabolic processes. Grazing or rural livestock productions from tropical countries do not receive mineral supplementation except for common salt $(\mathrm{NaCl})$ and must depend almost exclusively upon forage for their mineral requirements (McDowell, 1985). Although, lack of energy and protein are the main limiting factors in livestock products. Mineral deficiencies also seem to limit various production and reproduction traits in the animal. The role of trace elements in production is a key feature of sustainable agricultural systems. Tephrosia being a legume has all the nutrients in almost complete and balance quantity (Protein, Energy, Vitamins and Minerals). It contains phyto-estrogens which have accelerated efficient nutrients utilization. These species have wide adaptability and biodiversity (annual or biennial) depending on habitat and can be established through seedling

recruitment (Daniel 1871). Tephrosia
bracteolata is a useful plant of West Tropical Africa (Hutchinson et al., 1954). Guinea grass (Panicum maximum) is a widely distributed tussock lump forming grass that grows best on warm frost-free areas. It is considered the best grass for ruminant production and is highly relished by a goat which is readily available and stimulates ruminal microbial growth (Ajayi et al., 2005). Various works have been done in a combination of this legume and the grass on the performance characteristics of goats (Adeloye ,1994 and Anugwa et al., 2000). Ensuing hypothesis is that there is no significant difference in response from legume levels inclusion which informs the experimenting the effects of different levels of Tephrosia bracteolata on the macromineral balance in West African dwarf goats fed with concentrate.

\section{Materials and Methods}

\section{Experimental site}

The trials were carried out at the Teaching and Research Rocky Filer farm of University of 
Ibadan, Ibadan Oyo state (forest savannah Transition zone) located at 70151-70301 N and Longitude 30451 - 40001 East at an altitude of between 200 and 300 meters above sea level and climate is of sub-humid type. The soil is welldrained and belongs to the Alfisols (Rhodic Kandiustalf) order (FAO 2000).

\section{Pen Management}

The pens and metabolism cages were swept and dusted and were later fumigated with Dettol (Chloroxylenol $\circledast$, a strong antiseptic/disinfectant) manufactured by Reckitt Benckiser Ogun state, Nigeria at the rate of $27 \mathrm{ml}$ to 1 liter of water and also with Diazintol (Diazinon Dimpylate $®$ a strong and broad-spectrum insecticide manufactured by Alfasan International B.V.Holland), at the rate of $2 \mathrm{ml}$ to 1 litre of water. A mixture of used automobile engine oil (1 liter) and sieved wooden ash (250 gram) was basally applied on the floor to repel soldier ants, dorylus spp. Wood shaven was later spread on the floor of pens fortnightly applied and changed respectively until the end of the trial.

\section{Feed Materials}

Tephrosia bracteolata shoots were cut $50 \mathrm{~cm}$ above the ground from the Pasture and Range section of the farm and sorted into leaves (leaves plus fine stem up to $6 \mathrm{~mm}$ in diameter, Tarawali et al., 1995) and leaves were allowed to wilt overnight before feeding.

\section{Animal Management}

10 Bucks and 10 Does of West African Dwarf Goats breed and aged between 4 and 7 months with an average initial live weight of $5.79 \pm 0.60$ $\mathrm{kg}$ were used in the experiment. The goats collected from the homestead and local market within and outside the station's environment were on arrival lairage in the adaptation pen where they stayed before the commencement of the experiment. During this time, goats were dewormed with Levaject (Levamisole $\AA$ by SKM Pharma., India) at the rate of $1 \mathrm{ml} / 20 \mathrm{~kg} \mathrm{BW}$ which was applied intramuscularly; Ivomec (Ivermectin $\AA$ by SKM Pharma., India) was applied subcutaneously at $1 \mathrm{ml} / 40 \mathrm{~kg}$ BW around the shoulder blade. Terroxy L.A®. (Oxytetracycline long Acting by SKM Pharma., India) at the rate of $1 \mathrm{ml} / 10 \mathrm{~kg}$ was applied intramuscularly; they were also dipped in Diazintol solution and finally vaccinated against Peste des petits ruminants (PPR) using tissue culture Rinderpest vaccine (TCRV) at the rate of $1 \mathrm{ml} /$ animal subcutaneously (PPR) (Reynold et al., 1988). After which Tanvit (Multivitamin and anti-stress by SKM Pharma., India) was administered intramuscularly at the rate of $3 \mathrm{ml} /$ animal. During the 84-day long growth trials, animals were housed in individual pens and they were adjusted for 14 days before the commencement of feed offered and leftovers recordings. During the last 2 weeks of the trials, the animals were transferred to modified metabolism cages in preparedness for digestibility and the balance aspect of the experiment.

\section{Experimental Design and Treatments}

The animals were divided into 5 groups (4 each) after balancing for age and weight. Each group was randomly assigned to one of the five treatments and individual animals were completely randomized within the pens. Each animal was fed twice daily with both forages (4\% body weight of forage allowance) and with concentrate ( $1 \%$ body weight of concentrate allowance). Both allowances constitute the feed allowance which was $5 \%$ body weight of the animal as shown in Table 2. This feed allowance was constantly adjusted as animal weight changes. Each component was served in separate containers and ad libitum fresh drinking water was available to the animal.

Table 1: Dietary treatments allocation

\begin{tabular}{lcccc}
\hline \multicolumn{1}{c}{ Ingredients } & Tb20 & Tb40 & Tb60 & Tb80 \\
\hline $\begin{array}{l}\text { Tephrosia } \\
\text { bracteolate (Tb) }\end{array}$ & 20 & 40 & 60 & 80 \\
$\begin{array}{l}\text { Panicum } \\
\text { maximum (Pm) }\end{array}$ & 60 & 40 & 20 & - \\
$\begin{array}{l}\text { Tb }+ \text { Pm } \\
\text { forage }\end{array}$ & 4 & 4 & 4 & 4 \\
$\begin{array}{l}\text { allowance 80\%, } \\
4 \% \text { BW) }\end{array}$ & & & & \\
$\begin{array}{l}\text { Concentrate } \\
20 \%(1 \% \text { BW) }\end{array}$ & 1 & 1 & 1 & 1 \\
$\begin{array}{l}\text { Forage+ } \\
\text { Concentrate } \\
\text { (Feed allowance, }\end{array}$ & 5 & 5 & 5 & 5 \\
$5 \%$ BW) & & & & \\
\hline
\end{tabular}

The live weight of goats was measured at the beginning of the trial and subsequently at a weekly interval in the morning before the feed was offered. Daily feed intake, weight change, and mortality were recorded to assess the performance. To calculate daily feed intake, the amount of $T$ bracteolata, Panicum maximum and concentrate offered to and refused by each animal were recorded daily. Feed samples offered to the goats collected three times per week. Samples were oven-dried at $650 \mathrm{C}$ for 48 hours. For DM determination, samples were oven-dried at between $100-1050 \mathrm{C}$ for 48 hours in an oven at the beginning of the trial and subsequently at 


\section{Tephrosia bracteolate feeding in west African dwarf goat}

weekly intervals. The goats were transferred to metabolism cages in the last 12 days. This was made of welded wire mesh fitted with removable feeders and arranged for the quantitative collection of feces and urine separately under the same feeding and management during the growth trial. The animals were left to adjust" in the cages for 5 days. After which total feces and urine produced by individual animals were collected. In accordance with CIOMS (1985), offered and refused feed was recorded daily and samples bulked separately for each animal for the entire collection period. Total fecal output and urine were collected in the morning before feeding and watering. The feces were weighed fresh and $10 \%$ aliquots of each day's collection for each animal were taken and prepared for storage and DM determination as mentioned earlier. Feeds and fecal samples were separately and thoroughly mixed and milled to pass through a $0.60 \mathrm{~mm}$ sieve and stored in hermetically sealed containers before laboratory analysis. The urine was collected in a plastic tray placed under each cage, $10 \mathrm{ml}$ of $10 \%$ concentrated $\mathrm{H} 2 \mathrm{SO} 4$ was added to the tray daily to prevent microbial colonization and prevent $\mathrm{NH} 4$ volatilization from the urine. The total output of urine for the animal was measured and $10 \%$ aliquots were saved in stoppered and numbered plastic bottles and stored at $-50 \mathrm{C}$ until needed for chemical analysis.

Table 2: Concentrate Composition

\begin{tabular}{lc}
\hline Ingredients & Percentages \\
\hline $\begin{array}{l}\text { Sorghum brewery's waste } \\
\text { (DUSA) }\end{array}$ & 40.00 \\
Corn offal & 40.00 \\
Palm Kernel cake & 14.00 \\
Bone Meal & 2.00 \\
Oyster shell & 2.00 \\
Salt & 2.00 \\
\hline
\end{tabular}

\section{Chemical/ Laboratory Analysis}

Feed samples (Tephrosia bracteolata, Panicum maximum and Concentrate) and fecal samples were oven-dried for 48 hours at $650{ }^{\circ} \mathrm{C}$ for DM determination and sub-samples were ground through $1 \mathrm{~mm}$ sieve and stored in airtight containers. These sub-samples, urine samples, fecal samples were digested using the wet method, digested with concentrated Nitric acid (HNO3) and Perchloric acid $\left(\mathrm{HClO}_{3}\right)$ at a ratio of $5: 1$. The concentration of $\mathrm{Ca}, \mathrm{Mg}, \mathrm{Na}$, and $\mathrm{K}$ were estimated with atomic absorption spectrophotometer (model 490 Gallenkamp
London) while phosphorus was measured colorimetrically according to Harris and Popati (1954), as described by the Association of Official Analytical Chemist (A.O.A.C., 2000.)

\section{Statistical Analysis}

Data were further subjected to analyses using one-way ANOVA / completely randomized design using individual goats as replicates. Model sums of the square were partitioned to test the linear and quadratic trend of inclusion/supplementation using the general linear models procedures using S.A.S (2000) and significantly different means were separated using least significance difference at 0.5 level of probability in the same package.

\section{Results}

Tables 1 and 2 show the dietary treatment allocation and concentrate composition of the diet supplied to the goat while the chemometric value of supplied roughage and concentrate are shown in Table 3. Absorption ( $\mathrm{g} / \mathrm{day}$ ) of calcium (Ca) under different treatments is shown in Table 4. Intake $(\mathrm{g} /$ day $)$ of calcium was highest $(P<0.05)$ in Tb 60 (2.57) followed by Tb 80 (2.09), and the lowest was observed in Tb 20 (0.89). Absorption of calcium ( $\mathrm{g} /$ day) as indicated in Table 4 showed $(\mathrm{P}<0.05)$ that $\mathrm{Tb} 60>\mathrm{Tb} 80(1.29)>\mathrm{Tb} 40$ (0.79) >Tb 20 (0.64). Calcium retention also followed the same trend as absorption and found the highest retention in Tb60 $(P<0.05)$ than others.

Table 3: Chemo-metric value of supplied roughage and concentrate

\begin{tabular}{llll}
\hline $\begin{array}{l}\text { Nutrients } \\
\text { (\%DM) }\end{array}$ & $\begin{array}{l}\text { Tephrosia } \\
\text { bracteolat } \\
\mathbf{a}\end{array}$ & $\begin{array}{l}\text { Guine } \\
\mathbf{a} \\
\text { grass }\end{array}$ & $\begin{array}{l}\text { Concentrat } \\
\text { e }\end{array}$ \\
\hline Calcium & 1.42 & 0.72 & 1.84 \\
$\begin{array}{l}\text { Phosphoru } \\
\text { S }\end{array}$ & 0.29 & 0.35 & 0.79 \\
Magnesium & 0.68 & 0.49 & 0.77 \\
Ca:P & 4.90 & 2.06 & 2.33 \\
Sodium & 0.10 & 0.39 & 0.73 \\
Potassium & 1.25 & 1.36 & 0.62 \\
Ca:Mg & 2.09 & 1.47 & 2.39 \\
P:Mg & 0.43 & 0.71 & 1.03 \\
Na:K & 0.08 & 0.29 & 1.17 \\
k/Ca+Mg & 0.60 & 1.12 & 0.24 \\
\hline
\end{tabular}


Table 4: Calcium balance by goats fed Guinea grass and concentrate supplemented with increasing levels of Tephrosia bracteolata

\begin{tabular}{|c|c|c|c|c|c|c|c|}
\hline \multirow[b]{2}{*}{ Parameters } & \multicolumn{4}{|c|}{ Supplementation level } & \multirow[t]{2}{*}{ SEM } & \multicolumn{2}{|c|}{ Probability } \\
\hline & Tb 20 & Tb40 & Tb60 & Tb80 & & $\mathbf{L}$ & $\mathbf{Q}$ \\
\hline $\begin{array}{l}\text { Calcium intake } \\
\left(\mathrm{gd}^{-1}\right)\end{array}$ & 0.89 & 1.18 & 2.57 & 2.05 & 0.67 & $x$ & $x$ \\
\hline \multicolumn{8}{|c|}{ Calcium excretion } \\
\hline Feacal $\left(\mathrm{gd}^{-1}\right)$ & $\begin{array}{r}0.2 \\
5\end{array}$ & 0.39 & 1.00 & 0.76 & 0.14 & $x X X$ & Ns \\
\hline Urine $\left(\mathrm{gd}^{-1}\right)$ & $\begin{array}{r}0.0 \\
2\end{array}$ & 0.06 & 0.01 & 0.03 & 0.00 & $X X X$ & Ns \\
\hline Total $\left(\mathrm{gd}^{-1}\right)$ & $\begin{array}{r}0.2 \\
7\end{array}$ & 0.45 & 1.01 & 0.79 & 0.21 & $X X X$ & Ns \\
\hline \multicolumn{8}{|l|}{$\%$ of intake } \\
\hline (Faecal) & 28.09 & 33.05 & 38.91 & 37.07 & 2.47 & $x x$ & $x$ \\
\hline (Urine) & 2.25 & 5.08 & 0.39 & 1.46 & 1.15 & $X X X$ & Ns \\
\hline
\end{tabular}

\begin{tabular}{|c|c|c|c|c|c|c|c|}
\hline \multicolumn{8}{|c|}{ Calcium absorbed } \\
\hline$\left(\mathrm{gd}^{-1}\right)$ & 0.64 & 0.79 & 1.57 & 1.29 & 0.24 & $x$ & $x$ \\
\hline$\%$ of intake & 71.91 & 66.95 & 61.09 & 62.93 & 5.16 & $x$ & $x$ \\
\hline \multicolumn{8}{|l|}{ Calcium retained } \\
\hline$\left(\mathrm{gd}^{-1}\right)$ & 0.62 & 0.73 & 1.57 & 1.29 & 0.31 & $x$ & $x$ \\
\hline$\%$ of intake & 69.66 & 61.86 & 61.09 & 62.93 & 3.78 & $x$ & $x$ \\
\hline$\%$ of absorbed & 96.88 & 92.41 & 100 & 100 & 4.83 & Ns & Ns \\
\hline
\end{tabular}

abcd: means of the same row with different superscripts are significantly different $(P<0.05)$; SEM: Standard Error of Mean; +: Level of inclusion calculated as percentage of total daily feed allowance of $50 \mathrm{~g} D M \mathrm{~kg}-1$ body weight; \#: Probability for Linear $(L)$ and Quadratic $(Q)$ trends; $X: p<0.05 ; X X P<0.01 ; X X X P<0.001$.

There was a marked $(p<0.05)$ linear increase among treatments in Phosphorus intake which shows in Table 5 . Similarly, absorption ( $\mathrm{g} / \mathrm{day}$ ) and retention ( $\mathrm{g} /$ day) followed the same trend. In both cases, Tb20 shows the lowest and Tb80 shows the highest absorption and retention per day among treatments. Tb80 significantly differed from Tb20 in terms of phosphorus absorption and retention. No $P$ was found in urine during urine analysis. There was a distinct difference observed between $\mathrm{Ca}$ and $\mathrm{P}$ utilization especially in excretion through urine.

Magnesium ( $\mathrm{Mg}$ ) balance with increasing levels of Tephrosia bracteolata is shown in Table 6 . There was a slight linear and quadratic effect of Tb inclusion on its intake ( $\mathrm{g} /$ day) Tb40 (0.62) to Tb60 (1.77). There was similar trend of intake reflecting on the pattern ( $\mathrm{g} /$ day) of absorption
Tb40 (0.40) to Tb60 (1.13) and retention Tb40 (0.37) and Tb60 (1.10) respectively.

Sodium ( $\mathrm{Na}$ ) balance by WAD Goats fed Guinea grass and concentrate supplemented with increasing levels of Tephrosia bracteolate are shown in Table 7. In case of intake, absorbed and retained $\mathrm{Na}$ increasing trend was observed in treatment from Tb20 to Tb80. An increasing trend was observed from Tb20 to Tb80 in both quadratic and linear concerning $\mathrm{Na}$ absorption and retention from an inclusion level standpoint. Tb80 showed significantly higher $\mathrm{Na}$ absorption than Tb20. In case of $\mathrm{Na}$ retention, Tb80 showed the highest $(P<0.05)$ retention than other groups.

Potassium (K) balance is shown in Table 8 which revealed that marked and pronounced effect $(P<0.05)$ of the level was observed in intake ( $\mathrm{g} /$ day) which was increased from Tb20 (0.63) to Tb80 (1.65). In case of absorption ( $\mathrm{g} /$ day) 
increasing trends $(P<0.05)$ were observed from Tb20 (0.44) to Tb80 (1.25). In terms of retention (g/day), it was found that Tb40 (0.35) was lower $(P<0.05)$ than Tb20 (0.40) and Tb60 (0.99). Tb80 found the highest $(P<0.05) K$ retention than other groups.

\section{Discussion}

The values contained in Table 3 were all sufficiently within the range required $(\mathrm{Mg}: 0.04-$ 1.00, Ca: $0.18-1.04$ and $\mathrm{P}: 0.16-0.37$ ) by goat. The $\mathrm{K}$ and $\mathrm{Na}$ were also within or more than the range of goat requirements $(0.50-0.80$ and $0.04-0.10$ respectively) (Ogungbesan et al., 2011; Ogungbesan et al., 2014 ; Ogungbesan et al., 2014 ${ }^{\mathrm{b}}$ ). The highest apparent Ca observed in Tb60 reflects the advantages among others of legume which is efficient utilization of ion; although with the smallest intake this was also observed by Ogungbesan, et al., 2011. Apparent retention was highest in $\mathrm{Tb} 60$, which means more absorption takes place after digestion. This result corroborates the findings of Reid et al., (1987) and Robertson et al., (1996) Who reported that higher intake leads to higher fecal and urinary excretion of minerals, though the $\mathrm{Tb}$ increment did not influence linearly the balance. Various factors affect calcium utilization, such as plant factors, animal factors and the fate of nutrients in-vivo (Hacker and Ternouth, 1987). Besides, vitamin $\mathrm{D}$ plays an important role in $\mathrm{Ca}$ utilization which cannot be ignored. Calcium homeostasis is also regulated in a complex manner by parathyroid (PTH) and calcitonin by increasing and decreasing the serum level of calcium through a 'Push-pull feedback system' (Ogungbesan 2004).

Following the report of NRC (1980), phosphorus is absorbed in the small intestine and urinary excretion can occur only when it is in excess amount. $\mathrm{P}$ sources, intestinal $\mathrm{pH}$, lactose intake, iron, aluminium, manganese, potassium, magnesium, fat etc. can affect phosphorus utilization or metabolism (NRC 1980).

Table 5: Phosphorus balance by goats fed Guinea grass and concentrate supplemented with increasing levels of Tephrosia bracteolata

\begin{tabular}{|c|c|c|c|c|c|c|c|}
\hline \multirow[b]{2}{*}{ Parameters } & \multirow[b]{2}{*}{ Tb20 } & \multicolumn{3}{|c|}{ Supplementation level } & \multirow[t]{2}{*}{ SEM } & \multicolumn{2}{|c|}{ Probability } \\
\hline & & Tb40 & Tb60 & Tb80 & & $\mathbf{L}$ & $\mathbf{Q}$ \\
\hline $\begin{array}{l}\text { Phosphorus } \\
\text { intake }\left(\mathbf{g d}^{-1}\right)\end{array}$ & $0.28^{\mathrm{c}}$ & $0.31^{b c}$ & $0.34^{b}$ & $0.48^{a}$ & 0.03 & $x x x$ & Ns \\
\hline
\end{tabular}

\begin{tabular}{|c|c|c|c|c|c|c|c|}
\hline \multicolumn{8}{|c|}{ Phosphorus excretion } \\
\hline Feacal $\left(\mathrm{gd}^{-1}\right)$ & 0.01 & 0.01 & 0.01 & 0.01 & 0.00 & Ns & Ns \\
\hline Urine $\left(\mathrm{gd}^{-1}\right)$ & 0.00 & 0.00 & 0.00 & 0.00 & 0.00 & Ns & Ns \\
\hline Total $\left(\mathrm{gd}^{-1}\right)$ & 0.01 & 0.01 & 0.01 & 0.01 & 0.00 & Ns & Ns \\
\hline \multicolumn{8}{|l|}{$\%$ of intake } \\
\hline (Faecal) & $3.57^{\mathrm{a}}$ & $3.22^{\mathrm{a}}$ & $2.94^{\mathrm{b}}$ & $2.08^{c}$ & 0.52 & $x x x$ & Ns \\
\hline (Urine) & 0.00 & 0.00 & 0.00 & 0.00 & 0.00 & Ns & Ns \\
\hline \multicolumn{8}{|c|}{ Phosphorus absorbed } \\
\hline$\left(\mathrm{gd}^{-1}\right)$ & $0.27^{b}$ & $0.30^{\mathrm{ab}}$ & $0.33^{\mathrm{ab}}$ & $0.47 a$ & 0.10 & $x x x$ & Ns \\
\hline$\%$ of intake & 96.43 & 96.77 & 97.06 & 97.92 & 0.38 & Ns & Ns \\
\hline \multicolumn{8}{|c|}{ Phosphorus retained } \\
\hline$\left(\mathrm{gd}^{-1}\right)$ & $0.27^{\mathrm{b}}$ & $0.30^{\mathrm{ab}}$ & $0.33^{\mathrm{ab}}$ & $0.47^{\mathrm{a}}$ & 0.07 & $x x x$ & Ns \\
\hline$\%$ of intake & 96.43 & 96.77 & 97.06 & 97.92 & 1.83 & $x x x$ & Ns \\
\hline$\%$ of absorbed & 100 & 100 & 100 & 100 & 0.00 & Ns & Ns \\
\hline
\end{tabular}

abcd: means of the same row with different superscripts are significantly different $(P<0.05)$; SEM: Standard Error of Mean; +: Level of inclusion calculated as percentage of total daily feed allowance of $50 \mathrm{~g} D M \mathrm{~kg}-1$ body weight; \#: Probability for Linear $(L)$ and Quadratic $(Q)$ trends; $X: p<0.05 ; X X P<0.01 ; X X X P<0.001$. 
Ogungbesan et al. (2020) Bang. J. Anim. Sci. 49 (2):119-127

Table 6: Magnesium balance by goats fed Guinea grass and concentrate supplemented with increasing levels of Tephrosia bracteolata

\begin{tabular}{|c|c|c|c|c|c|c|c|c|}
\hline \multirow[b]{2}{*}{ Parameters } & \multicolumn{5}{|c|}{ Supplementation level } & \multirow[t]{2}{*}{ SEM } & \multicolumn{2}{|c|}{ Probability } \\
\hline & Tb 20 & Tb 40 & Tb 60 & Tb & 80 & & $\mathbf{L}$ & $\mathbf{Q}$ \\
\hline Magnesium & $0.64^{c}$ & $0.62^{c}$ & $1.77^{\mathrm{a}}$ & & $0.90^{\mathrm{b}}$ & 0.67 & $x$ & $x$ \\
\hline intake $\left(\mathrm{gd}^{-1}\right)$ & & & & & & & & \\
\hline \multicolumn{9}{|c|}{ Magnesium excretion } \\
\hline Feacal $\left(\mathrm{gd}^{-1}\right)$ & $0.23^{c}$ & $0.22^{c}$ & $0.64^{\mathrm{a}}$ & & $0.33^{\mathrm{b}}$ & 0.09 & $x$ & $x$ \\
\hline Urine $\left(\mathrm{gd}^{-1}\right)$ & $0.01^{b}$ & $0.03^{\mathrm{a}}$ & $0.03^{\mathrm{a}}$ & & $0.02^{\mathrm{b}}$ & 0.00 & $x$ & $\mathrm{x}$ \\
\hline Total $\left(\mathrm{gd}^{-1}\right)$ & $0.24^{c}$ & $0.25^{c}$ & $0.67^{a}$ & & $0.35^{\mathrm{b}}$ & 0.11 & $x$ & $\mathrm{x}$ \\
\hline \multicolumn{9}{|l|}{$\%$ of intake } \\
\hline (Faecal) & $35.93^{\mathrm{ab}}$ & $35.48^{\mathrm{ab}}$ & $36.15^{\mathrm{a}}$ & & $36.66^{\mathrm{a}}$ & 1.86 & $x$ & $x$ \\
\hline (Urine) & $1.56^{\mathrm{c}}$ & $4.83^{\mathrm{a}}$ & $1.69^{\mathrm{c}}$ & & $2.22^{\mathrm{b}}$ & 0.34 & $x$ & $x$ \\
\hline \multicolumn{9}{|c|}{ Magnesium absorbed } \\
\hline$\left(\mathrm{gd}^{-1}\right)$ & $0.41^{\mathrm{c}}$ & $0.40^{c}$ & $1.13^{\mathrm{a}}$ & & $0.66^{b}$ & 0.12 & $x$ & $\mathrm{x}$ \\
\hline$\%$ of intake & $64.06^{\mathrm{b}}$ & $64.51^{\mathrm{b}}$ & $63.84^{\mathrm{bc}}$ & & 73.33a & 1.94 & $x$ & $x$ \\
\hline \multicolumn{9}{|c|}{ Magnesium retained } \\
\hline$\left(\mathrm{gd}^{-1}\right)$ & $0.40^{c}$ & $0.37^{c d}$ & $1.10^{\mathrm{a}}$ & & $0.55^{\mathrm{b}}$ & 0.16 & $x$ & $x$ \\
\hline$\%$ of intake & $62.50^{\mathrm{a}}$ & $59.67^{\mathrm{ab}}$ & $62.14^{\mathrm{a}}$ & & $61.11^{\mathrm{a}}$ & 2.18 & $x$ & $\mathrm{x}$ \\
\hline$\%$ of absorbed & 97.56 & $92.50^{\mathrm{b}}$ & $97.34^{\mathrm{a}}$ & & $83.33^{c}$ & 1.49 & $x$ & $x$ \\
\hline
\end{tabular}

abcd: means of the same row with different superscripts are significantly different $(P<0.05)$; SEM: Standard Error of Mean; +: Level of inclusion calculated as percentage of total daily feed allowance of $50 \mathrm{~g} \mathrm{DM} \mathrm{kg}-1$ body weight; \#: Probability for Linear $(L)$ and Quadratic $(Q)$ trends; $X: p<0.05 ; X X P<0.01 ; X X X P<0.001$.

An irregular pattern was reported in terms of $\mathrm{Tb}$ increment in magnesium absorption and retention but was in line with the assertion of NRC (1980) that urinary excretion is almost usually a reflection of the quantity of magnesium absorption. Its absorption could also be impaired by $\mathrm{K}, \mathrm{Ca}, \mathrm{Mg}$, fat, sulfate, citrate and transaconitate (Church 1988). Mg metabolism can also be influenced by $\mathrm{k} /(\mathrm{Ca}+\mathrm{Mg})$ factor which implies that high potassium content in the diet can interfere with absorption of $\mathrm{Mg}$ along the brush border of intestine, its high ruminal solubility, rapid absorption in the rumen and the GI tract relative to others has been confirmed and cataloged by Van Eys and Reid (1987). Master and white (1996) also indicated the interaction of $\mathrm{N}, \mathrm{P}, \mathrm{K}$, and $\mathrm{Na}$ on $\mathrm{Mg}$ absorption and $\mathrm{Mg}$ movement through the peritoneal cavity by "dialysis" against $\mathrm{Ca}$ free medium without necessarily reflecting on the serum chemistry of the animal. The absence of sodium in urine confirms the report of the Church (1988) that it is almost completely reabsorbed from the colon (Large intestine) of ruminants. He also stated that the uptake from the small intestine is influenced by the presence of sugars and amino acids (Church DC, 1988). Similarly, the ratio of
$\mathrm{Na}: \mathrm{K}$ is also vital in the absorption of both element, which should not be less than 0.1. Na deficiency, although leads to "geophagia" which indirectly increases the iron intake, its functions in the maintenance of the acid-base balance and the buffering system as well as its role in the absorption of nutrients especially protein cannot be overlooked (Master and White, 1996).

The last electrolyte to be considered is potassium, whose intake and absorption was linearly affected by supplementation of different levels of $\mathrm{Tb}$, which is in line with the higher intake, fecal and urinary pattern reported by Ogungbesan 2004. In addition substantial urinary has been confirmed by Ammerman et al., (1995). In general, minerals utilization can be affected by different plant factors like mineral concentration and mineral availability. These can be influenced by organic or inorganic bio crystallization. Because the inorganic form is relatively difficult to be absorbed by the animal especially $\mathrm{Ca}$ and $\mathrm{P}$ (hydroxylapatite and whitlockite respectively) which is processes that occurred during the deposition of inorganic constituent and also a basic phenomenon of plant growth (McManus et al., 1979). 
Table 7: Sodium balance by goats fed Guinea grass and concentrate supplemented with increasing levels of Tephrosia bracteolata

\begin{tabular}{|c|c|c|c|c|c|c|c|c|c|}
\hline \multirow[b]{2}{*}{ Parameters } & \multirow[b]{2}{*}{ Tb 20} & \multicolumn{5}{|c|}{ Supplementation level } & \multirow[t]{2}{*}{ SEM } & \multicolumn{2}{|c|}{ Probability } \\
\hline & & Tb 40 & Tb & 60 & Tb & 80 & & $\mathbf{L}$ & $\mathbf{Q}$ \\
\hline $\begin{array}{l}\text { Sodium } \\
\text { intake }\left(\mathbf{g d}^{-1}\right)\end{array}$ & $0.10^{\mathrm{bc}}$ & $0.14^{\mathrm{ab}}$ & & $0.12^{b}$ & & $0.16^{\mathrm{a}}$ & 0.04 & $x$ & $x$ \\
\hline \multicolumn{10}{|c|}{ Sodium excretion } \\
\hline Feacal $\left(\mathrm{gd}^{-1}\right)$ & $0.02^{\mathrm{a}}$ & $0.03^{\mathrm{a}}$ & & $0.02^{\mathrm{a}}$ & & $0.02^{\mathrm{a}}$ & 0.00 & Ns & $x$ \\
\hline Urine $\left(\mathrm{gd}^{-1}\right)$ & $0.00^{\mathrm{a}}$ & $0.00^{a}$ & & $0.00^{\mathrm{a}}$ & & $0.00^{\mathrm{a}}$ & 0.00 & Ns & Ns \\
\hline Total $\left(\mathrm{gd}^{-1}\right)$ & $0.02^{\mathrm{a}}$ & $0.03^{a}$ & & $0.02^{\mathrm{a}}$ & & $0.02^{\mathrm{a}}$ & 0.00 & Ns & $x$ \\
\hline \multicolumn{10}{|l|}{$\%$ of intake } \\
\hline (Faecal) & $20.00^{\mathrm{a}}$ & $21.42^{\mathrm{a}}$ & & $16.66^{\mathrm{b}}$ & & $12.50^{c}$ & 1.52 & $x x$ & $x$ \\
\hline (Urine) & $0.00^{\mathrm{a}}$ & $0.00^{\mathrm{a}}$ & & $0.00^{\mathrm{a}}$ & & $0.00^{\mathrm{a}}$ & 0.00 & Ns & Ns \\
\hline \multicolumn{10}{|c|}{ Sodium absorbed } \\
\hline$\left(\mathrm{gd}^{-1}\right)$ & $0.08^{c}$ & $0.11^{\mathrm{b}}$ & & $0.11^{\mathrm{b}}$ & & $0.14^{\mathrm{a}}$ & 0.01 & $x x$ & Ns \\
\hline$\%$ of intake & $80.00^{c}$ & $78.57^{d}$ & & $83.33^{b}$ & & $87.50^{\mathrm{a}}$ & 2.46 & $x$ & $x$ \\
\hline \multicolumn{10}{|c|}{ Sodium retained } \\
\hline$\left(\mathrm{gd}^{-1}\right)$ & $0.08^{c}$ & $0.11^{\mathrm{b}}$ & & $0.10^{\mathrm{bc}}$ & & $0.14^{\mathrm{a}}$ & 0.01 & $x$ & $x$ \\
\hline$\%$ of intake & $80.00^{c}$ & $78.57^{d}$ & & $83.33^{b}$ & & $87.50^{\mathrm{a}}$ & 2.65 & $x$ & $x$ \\
\hline$\%$ of absorbed & $100^{\mathrm{a}}$ & $100^{\mathrm{a}}$ & & $100^{\mathrm{a}}$ & & $100^{\mathrm{a}}$ & 0.00 & Ns & Ns \\
\hline
\end{tabular}

abcd: means of the same row with different superscripts are significantly different $(P<0.05)$; SEM: Standard Error of Mean; +: Level of inclusion calculated as percentage of total daily feed allowance of $50 \mathrm{~g} D M \mathrm{~kg}-1$ body weight; \#: Probability for Linear $(L)$ and Quadratic $(Q)$ trends; $X: p<0.05 ; X X P<0.01 ; X X X P<0.001$.

Table 8: Potassium balance by goats fed Guinea grass and concentrate supplemented with increasing levels of Tephrosia bracteolata

\begin{tabular}{|c|c|c|c|c|c|c|c|}
\hline \multirow[b]{2}{*}{ Parameters } & \multicolumn{4}{|c|}{ Supplementation level } & \multirow[t]{2}{*}{ SEM } & \multicolumn{2}{|c|}{ Probability } \\
\hline & Tb20 & Tb40 & Tb60 & Tb80 & & $\mathbf{L}$ & $\mathbf{Q}$ \\
\hline $\begin{array}{l}\text { Potassium } \\
\text { intake }\left(\mathbf{g d}^{-1}\right)\end{array}$ & $0.63^{c}$ & $0.84^{\mathrm{b}}$ & $1.54^{\mathrm{a}}$ & $1.65^{\mathrm{a}}$ & 0.18 & $x x x$ & Ns \\
\hline \multicolumn{8}{|c|}{ Potassium excretion } \\
\hline Feacal $\left(\mathrm{gd}^{-1}\right)$ & $0.19^{c}$ & $0.38 a$ & $0.32^{\mathrm{b}}$ & $0.40^{\mathrm{a}}$ & 0.07 & $x x$ & $x$ \\
\hline Urine $\left(\mathrm{gd}^{-1}\right)$ & $0.04^{c}$ & $0.11^{\mathrm{b}}$ & $0.23^{\mathrm{a}}$ & $0.06^{c}$ & 0.01 & $x$ & $x$ \\
\hline Total $\left(\mathrm{gd}^{-1}\right)$ & $0.23^{c}$ & $0.49^{b}$ & $0.55^{a}$ & $0.46^{\mathrm{b}}$ & 0.12 & $x$ & $x$ \\
\hline \multicolumn{8}{|l|}{$\%$ of intake } \\
\hline (Faecal) & $30.15^{\mathrm{b}}$ & $45.23^{\mathrm{a}}$ & $20.79^{d}$ & $24.24^{c}$ & 2.16 & $x$ & $x$ \\
\hline (Urine) & $6.34^{\mathrm{b}}$ & $13.09^{\mathrm{a}}$ & $14.9^{3 a}$ & $3.63^{c}$ & 1.04 & $x$ & $x x$ \\
\hline \multicolumn{8}{|c|}{ Potassium absorbed } \\
\hline$\left(\mathrm{gd}^{-1}\right)$ & $0.44^{\mathrm{b}}$ & $0.46^{\mathrm{b}}$ & $1.22^{\mathrm{a}}$ & $1.25^{\mathrm{a}}$ & 0.18 & $x x x$ & Ns \\
\hline$\%$ of intake & $69.84 a$ & $54.76^{c}$ & $79.22^{\mathrm{a}}$ & $75.75^{\mathrm{a}}$ & 2.60 & $x x$ & $x$ \\
\hline \multicolumn{8}{|c|}{ Potassium retained } \\
\hline$\left(\mathrm{gd}^{-1}\right)$ & $0.40^{c}$ & $0.35^{d}$ & $0.99^{b}$ & $1.19^{\mathrm{a}}$ & 0.07 & $x x$ & $x$ \\
\hline$\%$ of intake & $63.49 b$ & $41.66^{c}$ & $64.28^{\mathrm{b}}$ & $72.12^{\mathrm{a}}$ & 2.86 & $x x$ & $x$ \\
\hline$\%$ of absorbed & $90.90^{\mathrm{b}}$ & $76.08^{d}$ & $81.14^{c}$ & $95.20^{\mathrm{a}}$ & 1.64 & $x$ & $x$ \\
\hline
\end{tabular}

abcd: means of the same row with different superscripts are significantly different $(P<0.05)$; SEM: Standard Error of Mean; +: Level of inclusion calculated as percentage of total daily feed allowance of $50 \mathrm{~g} D M \mathrm{~kg}-1$ body weight; \#: Probability for Linear (L) and Quadratic (Q) trends; $X: p<0.05 ; X X P<0.01 ; X X X P<0.001$. 
The amount and distribution within the various cell wall fractions are known as bioavailability. If high mineral content is present in non-degradable fraction, like the ligno-cellulosic portion, it will not be easily solubilized or released for absorption (Serra et al, 1996). Digestibility of feed matrix and antagonistic and synergistic effect of different nutrients also affect mineral utilization. The presence of phytates and oxalates in the diet interfere the utilization of $\mathrm{Mg}, \mathrm{Ca}, \mathrm{P}$ and $\mathrm{Zn}$ (Ogungbesan et al., 2005). Animal factors like appetite, ruminal microbial population dynamics, genotypic or phenotypic differences, age, sex, physiological states also affect mineral utilization. Production and reproduction demand, production type that influences activity and storage capacity can determine the "True absorptive coefficient" (TAC) that dictates retention, excretion and storage or functional pool nutrient mobilization in the entire animal system (Jarrige, 1999).

\section{Conclusion}

The results of the experiment show the utilization of different vital minerals which indicate the advantages and importance of legumes like $T$. bracteolata in WAD goat diet. In conclusion, T.bracteolata can be used as a roughage source for goats without any remarkable adverse or, side or ill effects which affect the well-being of animals feeding. It can be recommended that as almost all nutrient utilization (retention) increased linearly with levels, other trials like carcass analysis, reproductive performances can be carried out on goats and other ruminants.

\section{Conflict of interest}

There is no conflict of interest among the authors.

\section{References}

AOAC (2000). Official method of Analysis, Association of Analytical Chemist 20th edn. Washington D.C

Adeloye AA (1994). Preliminary investigation of Parkia filicoidea and Tephrosia bracteolata in Western-Nigeria. Nigeria Journal of Animal production 21: 105-107.

Ajayi DA, JA Adeneye and FT Ajayi (2005). Intake and nutrients utilization of West African dwarf goats fed mango (Mangifera indica), Ficus (Ficus thoningii), Gliricidia (Gliricidia sepium) foliages and concentrate as supplements to basal diet of Guinea Grass (Panicum maximum) World Journal Of Agricultural Science 1 (2):184-189.
Ammerman CB, DH Baker and AJ levis (1995). Bioavailability of nutrient for Animal: Aminoacid, minerals and vitamins. Academic Press. P 441.

Anugwa FO, AI Okwori and PO Ekwuno (2000). Feed intake, nutrient digestibility and nutrient value for goats of Panicum maximum and selected browse in the southern guinea savannah zone in Nigeria. In Animal Production in the new millennium: Challenges and options. Proceedings of 25th Annual Conference of N.S.A.P. at Michael Okpara Univ. of Agric. Umudike, Abia state. Nigeria Ikachukwu et al. Pg $63-66$.

CIOMS (1985).International guideline principles for biomedical research involving animals. Council for international organization of medical sciences .Test of guidelines http:www.cioms.ch/fram

Church DC (1988). The Ruminant Animal: Digestive physiology and Nutrition. Waveland Press Inc.Illinois U.S.A 564 p.

Daniel Oliver (1871). Floral of Tropiacal Africa. FRfls Volume II leguminosea to Ficodea. Recive L and co. 5 Herietta Street covent Garden. Ash fordKent England pg 106-115.

FAO (2000). World reference base for soil resources, 2000: A framework for international classification,correlation, and communication. Rome: Food and Agriculture Organization of the United Nations. $128 \mathrm{Pp}$.

Hacker JB and JH Ternouth (1987). The nutrition of herbivores. Academic Press New York 552PP

Harris WD and P Popati (1954) Determination of the phosphorus contents in lipids. American Oil and Chemical Society Journal 31: 124-129

Hutchinson J and JM Dalziel (1954) (second ed.), Flora of West Tropical Africa, Vol. 1.

Jarrige JA (1999). Ruminant Nutrition. Reccommended allowance and feed tables INRA France Pp 49-59.

Mac Dowell and L Russell (1985). Nutrition of grazing ruminants warm in climates Academic Press New York $443 \mathrm{Pp}$.

Master DG and CL White (1996). Detection and treatment of mineral nutrition problem in grazing sheep. A.C.I.A.R. Canberra. Pg 4-119.

McManus WR, RG Anthony, LL Grout, AS Malin and VNE Robinson (1979). Bio crystallization of mineral materials in forage plant cell walls Australian Journal of Agricultural Research 30: 635-49.

NRC (1980) National Research council. Mineral tolerance of domestic animals. N.A.S Washington D.C. 577 (Pp)

Ogungbesan AM (2004). Production and utilization of Tephrosia bracteolata (Gull et Perr) as forage for most African dwarf goat in south-western Nigeria. Ph.D Thesis Animal science Department U.I Ibadan Nigeria.

Ogungbesan AM, AO Ogunyemi and $\mathrm{Y}$ Olatifede (2005). Some Tephrosia bracteolata's (Gull et 
Perr) anti-nutrients response to time of planting: In the potential; and limitation of self sufficiency in livestock production in Nigeria 10th Anniversery and conference. [A.S. A.N. Odua conference hall UNAD Ado. Ekiti Sep 1014. J.A oluyemi and Aye. P.A (eds) pg 222224.

Ogungbesan AM, M Bamikole, K Adeyemi, M Omisande and AO Akinsoyinu (2011). Minerals in sole nitrogen fertilized-, legume interceded Panicum maximum (Jacq) and stylosanthes hamata (C.V Verano (L) Taub) and their interaction in relation to nutrients requirement. In: Value re-orientation in animal production. A key to national food security and stable economy. Proc.36th Ann. Conf. NSAP. At merit house/Raw material research and development council, Abuja. A. Adeniyi, A. A. Olatunji EA and Gana, E.S. (eds). 13-16 March Pg 574.

Ogungbesan AM, OE Fasina, GA Adeleke and AN Fajemisin (2014a) Tephrosia bracteolata (Guil Et Perr)-Panicum Maximum (Jacq) combinations utilization By West African Dwarf Goats. African Journal of Livestock Extension 14: 41-47.

Ogungbesan AM, OE Fasina, A Lamidi and AN Fajemisin (2014b) Macro elements utilization in W.A.D. does fed combined levels of Andropogon gayanus (Kunthz) and Gliricidia sepium (Jacq) with cassava offal based concentrate .African Journal of Livestock Extension 14; $65-71$.
Reid RL, WC Templeton Jnr, ST Ranny and WV Thayn WV (1987) Digestibility intake and Mineral utilization of combination of grasses and legumes by lambs. Journal of Agricultural Science (Cambridge) 64: 1725-34.

Reynolds H, AN Attah Krah, and PA Francis (1998). Alley farming with Livestock-Guide Lines P.M.B. 5320 Adiss-Baba. Ethiopia.

Robertson BM, T Magneri, A Dougon, MA Holmes and RA Hunter (1996). The effect of coal mine pit water on the productivity of cattle: Mineral intake, retention, excretion and the water balance in growing steers. Australian Journal Agricultural Research 47: 961-74.

Serra SD, AB Serra, T Ichinohe, T Harvinoto and T Fujihara (1996). Amount and distribution of dietary minerals in selected phillipine forages. Asia-Australasia Journal of Animal Science 9: 139-147.

Statistical Analysis systems (2000). SAS/STAT: Guide for personal computers. Version 6, S.A.S Inst. Cary New York U.S.

Van Eys JE and RL Reid (1987) Ruminal solubility of nitrogen and minerals from fescue and fescueclover herbage. Journal of Animal Science 6: 1101-1112. 